\title{
Which criteria matter most in the evaluation of venture capital investments?
}

\author{
José Carlos Nunes \\ Santarém School of Management and Technology, Polytechnic Institute of Santarém, Santarém, \\ Portugal \\ Elisabete Gomes Santana Félix \\ CEFAGE-UÉ, Management Department, University of Évora, Évora, Portugal \\ Cesaltina Pacheco Pires \\ CEFAGE-UÉ, Management Department, University of Évora, Évora, Portugal
}

Corresponding Author: Elisabete Gomes Santana Félix

Corresponding Author Email: efelix@,uevora.pt

\section{Acknowledgments}

The authors would like to thank the VCs who were kind enough to participate in this work and the comments and suggestions of anonymous referees to this work. The authors gratefully acknowledge partial financial support from FCT (Fundação para a Ciência e Tecnologia), program POCTI.

\section{Biographical Details}

\section{José Carlos Nunes,}

Master in Management, with specialization in Entrepreneurship and Innovation, University of Évora, Portugal (since 2009); Is a Lecturer at the Santarém School of Management and Technology. Research Insterests: Venture capital; Entrepreneurship; Microeconomics.

Address: Santarém School of Management and Technology, Polytechnic Institute of Santarém, Santarém, Portugal. Complexo Andaluz, Apartado 295, 2001-904 Santarém, Portugal. 


\section{Elisabete Gomes Santana Félix,}

$\mathrm{PhD}$ in Management, with specialization in Finance, ISCTE, Portugal (2008); Assistant Professor of the University of Évora (since 2008). Research Interests: Venture capital; Real Options; Elaboration and Evaluation Investment Projects; Social Entrepreneurship.

Address: CEFAGE-UÉ, Management Department, University of Évora, Évora, Portugal. Largo dos Colegiais, $n^{\circ} 2,7000-803$ Évora, Portugal.

\section{Cesaltina Pacheco Pires,}

PhD in Economics, MIT, EUA (1994); Associated Professor of the University of Évora. Research interests: Industrial organization; Game theory; Decision theory.

Address: CEFAGE-UÉ, Management Department, University of Évora, Évora, Portugal. Largo dos Colegiais, $n^{\circ} 2,7000-803$ Évora, Portugal.

\section{Structured Abstract}

Purpose - This study identifies the importance assigned to the various criteria used by the Portuguese Venture Capitalists (VCs) to evaluate and select early stage venture capital projects.

Design/methodology/approach - The data was collected through a questionnaire answered by 20 Portuguese VCs. We use descriptive statistics techniques and non-parametric tests to identify the most valued criteria and test differences in the importance assigned to the criteria of several types of VCs and investments.

Findings - The study reveals that personality and experience of the entrepreneur and of the management team are the most valued groups of criteria. VCs with a majority of private share capital value more the personality of the entrepreneur and management team than the companies with a majority of public share capital. Additionally, the VCs that did not yet internationalize consider the personality of the entrepreneur and management team and the financial aspects, to be more important than the VCs that have already expanded abroad.

Originality/value - It provides evidence on the VCs behaviour in a small venture capital market. Since most of the existing literature on this area refer to large VC markets, the present study is important to investigate whether the conclusions reached by the previous studies can be extended to a small VC market. Also, this study is a contribution to the literature on the internationalization of VCs and it is the first study that explores the impact of the VCs being internationalized on the value given to the various selection criteria of early stage venture capital projects.

Keywords: Venture capital; Evaluation criteria; Early stage investments; Internationalization.

JEL classification: $G 24$; $G 32$.

Article classification: Research Paper. 